\title{
PRAKTIK KERJA SAMA BISNIS AYAM POTONG PERSPEKTIF EKONOMI SYARIAH DI KECAMATANJEKAN RAYA
}

\author{
Sri Mandalika dan Enriko Tedja Sukmana \\ IAIN Palangka Raya
}

\begin{abstract}
The purpose of this research was to answer these problems. Based on the above issues, this type of research in this thesis was using qualitative research with descriptive approach. Data collection techniques in this research were interview, observation and documentation. The result of this research, namely: (1) cooperation practice of meat-producing chicken was done by the supplier (capital contribution) and managers (capital contributions and skill) with the provisions of the results namely: IDR 1,200 per kilograms (stuck). (2) the cooperation practice of meat-producing chicken business in Jekan Raya District was incompatible with Musharaka contract because the the result obtained before acquiring the real advantage and the disadvantages were not divided according to the capital portions of both parties.
\end{abstract}

Keywords: practice, business, and musharaka

\section{PENDAHULUAN}

\section{Latar Belakang}

Manusia sebagai makhluk hidup memiliki kebutuhan, salah satunya kebutuhan akan pangan. Kebutuhan pokok manusia diantaranya adalah daging. Daging yang paling diminati masyarakat Indonesia, khususnya kota Palangka Raya adalah daging ayam, selain harganya terjangkau, dan prosesnya pun tidak lama seperti daging sapi. Ada beberapa pengelolaan ayam di Palangka Raya. Namun pengelolaan ayam potong terbesar di kota Palangka Raya

Rajawali PS beralamat di Jalan Karanggan Ujung, khususnya di Kecamatan Jekan Raya salah satunya menggunakan sistem per kilo. Ada yang disebut pemilik modal dan ada yang disebut pengelola. Di mana ada 1 pihak pemilik modal dan banyak pihak yang mengelola. Pemilik modal bertindak sebagai pihak yang menyediakan bibit ayam, penyedia makan, vaksin, obatobatan serta vitamin, dan pemasok nanti yang akan mengambil ayam-ayam tersebut pada tiba waktu panen nanti. Pengelola bertindak sebagai pemelihara serta berkewajiban memberikan makan, minum, obat-obatan dan vitamin serta pengelola yang bertanggung jawab menyediakan kandang serta menanggung biaya listrik.

Dunia bisnis, tak asing jika kita sering mendengar yang namanya untung dan rugi. Begitu pula dalam bisnis ayam potong, apabila harga ayam dipasar melonjak naik maka pemasok untung, sebaliknya jika harga ayam potong di pasaran turun drastis pemasok akan mengalami kerugian besar-besaran. Tak hanya itu, pada kenyataannya bahkan pihak pemasok akan menjual beberapa mobil operasionalnya untuk membayar gaji karyawannya. Lain halnya dengan pihak pengelola, tak peduli dengan harga di pasaran naik atau turun, maka pihak pengelola tetap (flat) mendapatkan keuntungan perkilo Rp 1200,- dari berat ayam per ekornya (stagn). Namun pada hakikatnya, dalam syirkah keuntungan akan dibagi di antara para mitra usaha dengan bagian yang telah ditentukan oleh mereka. Pembagian keuntungan tersebut bagi setiap mitra usaha harus ditentukan sesuai bagian tertentu atau presentasi. Tidak ada jumlah yang pasti yang dapat ditentukan bagi pihak manapun di awal akad. Faktanya tidak demikian, pemasok akan mendapatkan keuntungan yang sebesar-besarnya apabila harga ayam di pasaran naik, sebaliknya 
pemilik modal akan mengalami kerugian apabila harga ayam di pasaran turun drastis, lain halnya dengan pengelola yang akan mendapatkan keuntungan tetap tidak tergantung pada harga di pasaran. Oleh karena itu, jelas terlihat pihak mana yang semakin dikayakan dan pihak mana yang hanya jalan ditempat (stagn) atau dirugikan.

Berdasarkan uraian di atas, peneliti mencoba merumuskan permasalahan yang akan diteliti sebagai berikut.

1. Bagaimana latar belakang praktik kerja sama bisnis ayam potong di kecamatan Jekan Raya?

2. Bagaimana penerapan bagi hasil praktik kerja sama bisnis ayam potong di Kecamatan Jekan Raya dengan berdasarkan akad Musyarakah?

\section{Kajian Teori dan Konsep}

Akad

Bahasa Arab ada dua istilah yang berkaitan dengan perjanjian atau kontrak, yaitu kata akad (al-'aqadu) dan kata 'ahd (al-ahdu), al-Qur'an memakai kata pertama dalam arti perikatan atau perjanjian, sedangkan kata yang kedua berarti masa, pesan, penyempurnaan dan janji atau perjanjian.

\section{Syirkah-Musyarakah}

Syirkah secara etimologis mempunyai arti pencampuran (ikhlitath), yakni bercampurnya salah satu dari dua harta dengan harta lainnya, tanpa dapat dibedakan keduanya. Menurut ulama Hanafiah, syirkah secara istilah adalah penggabungan harta (dan/ atau keterampilan) untuk dijadikan modal usaha dan hasilnya yang berupa keuntungan atau kerugian dibagi bersama.

\section{Pembiayaan Musyarakah}

Pembiayaan adalah penyediaan dana atau tagihan yang dipersamakan dengan itu berupa: Transaksi bagi hasil dalam bentuk musyarakah. Akad musyarakah adalah transaksi penanaman dana dari dua atau lebih pemilik dana dan/atau barang untuk menjalankan usaha tertentu sesuai syariah dengan pembagian hasil usaha antara kedua belah pihak berdasarkan proporsi modal masing-masing.

\section{Keadilan dalam Islam}

Perhatian terhadap keadilan tidak saja menjadi concern ekonomi Islam, tetapi juga menjadi perhatian berbagai ideologi besar lainnya didunia. Meskipun keadilan merupakan konsep dan kebutuhan global, namun tidak berarti bahwa konsep tersebut memiliki aksentuasi yang sama antar satu masyarakat dengan masyarakat lain dan antar satu ideologi dengan ideologi lain.

\section{Etika Bisnis Islam}

Istilah etika sering di artikan sebagai suatu perbuatan standar (standar of conduct) yang memimpin individu dalam membuat keputusan. Etika adalah suatu studi perbuatan yang saat dan yang benar dan pilihan moral yang di lakukan seseorang. Selain itu menurut Choirul Fuad Yusuf yang dikutip oleh Muhammad, etika adalah bidang normatif yang menegaskan secara tegas batas-batas wilayah antara apa yang seharusnya dengan apa yang tidak seharusnya di lakukan seseorang. 


\section{METODE}

Penelitian ini menggunakan jenis penelitian kualitatif. Penelitian kualitatif deskriptif merupakan penelitian yang dimaksudkan untuk mengumpulkan informasi mengenai suatu gejala yang ada, yaitu keadaan gejala menurut apa adanya saat penelitian dilakukan. Pendekatan kualitatif deksriptif dalam penelitian ini dimaksudkan agar peneliti dapat mengetahui dan menggambarkan apa yang terjadi dalam lokasi penelitian secara lugas dan terperinci serta berusaha untuk mengungkapkan data mengenai "Praktik Kerja Sama Bisnis Ayam Potong Perspektif Ekonomi Syariah di Kecamatan Jekan Raya”. Dengan demikiam, data yang didapat murni dari responden langsung, agar tidak ada kemungkinan data yang di dapat palsu atau rekayasa.

\section{HASIL DAN PEMBAHASAN}

Penelitian dilakukan selama tiga bulan dari Januari sampai Maret. Dengan mewawancarai 6 subjek yang telah dipilih oleh penulis dengan menggunakan teknik purposive sampling berdasarkan ciri-ciri yang dimiliki sampel itu. Peneliti menganalisis bahwa awal kepercayaan dimulai dengan pelaksanaan transaksi (akad/aqd) yang sesuai dengan Al-Qur'an dan Hadist. Segala suatu pelaksanaan transaksi tersebut di lakukan guna meniadakan angka penipuan, persengketaan, ataupun segala macam dampak negatif yang timbul dari suatu transaksi. Akad yang seharusnya yaitu ketika akad dijalani dengan fair (adil), maka akan menghasilkan benefit (keuntungan) yang halal dan berkah.

Akad yang terjadi di lapangan, peneliti mengutip dari pernyataan Bos ayam:

"oh iya, gampang aja soal itu. Semua saya yang tanggung, pakan, obat-obatan, vitamin, vaksin dan bibit ayam. 1kg ayam, bapak dapat Rp 1.200,00."

Di sini seharusnya ada kesepakatan dua belah pihak. Apakah pihak ke-2 mau menerima upah Rp 1200,- ayam per kg ayam. Lalu, apakah upah Rp 1200,- itu diberikan saat ayam dipasaran dengan harga standar atau harga di pasaran melonjak naik, atau upah tersebut diberikan sudah baku di awal tidak peduli apakah harga ayam dipasaran naik atau turun. Seharusnya ada perbedaan upah di saat harga ayam di pasaran standar atau melonjak naik, khususnya saat hari-hari besar, seperti hari raya Idul Fitri atau pada saat natal dan tahun baru. Karena, yang mengelola ayam itu adalah pihak kedua, mulai dari ayam umur 1 hari sampai ayam siap dipanen, yang mengobati ayam jika dilanda penyakit. Sudah seharusnya di sini pihak kedua juga mempunyai hak untuk menerima upah Rp 1200 per kg atau tidak di saat ayam di pasaran harga standar atau melonjak naik. Tetapi fakta real di lapangan, hal ini tidak dilihat oleh peneliti.

Menurut peneliti ini tidak sesuai, karena Subjek Akad yaitu Al-Aqid (orang yang akad) adalah orang yang melakukan akad, yaitu orang kesatu dan orang kedua sebagai pihak-pihak yang melakukan perserikatan. Orang yang melaksanakan akad disyaratkan pandai berakad atau ahli. Orang yang ahli dalam berakad dibagi menjadi dua, yaitu ahli wajib dan ahli 'ada. Ahli wajib yaitu kepantasan atau kelayakan seseorang untuk menetapkan suatu keharusan yang menjadi haknya, seperti pantas menetapkan harga yang harus diganti oleh orang yang telah merusak atau menetapkan harga. Bagian ini memiliki dua unsur, yaitu: 1) unsur Ijabi, yaitu kepantasan untuk mengambil haknya; dan 2) unsur Salabi, yaitu kepantasan untuk melaksanakan kewajibannya. Seharusnya dalam dua orang yang berserikat harus ada unsur kepantasan untuk mengambil dan melaksanakan haknya. Hal ini dimaksudkan agar terciptanya prinsip saling kerelaan kedua belah pihak di saat kerja sama bisnis berjalan.

Musyarakah dikatakan sebagai upaya kemitraan atau partnership atau participation sehingga dalam ekonomi kemitraan terdapat upaya dan usaha menerapkan prinsip tolongmenolong. 
Peneliti menganalisis bahwa dalam musyarakah keuntungan dibagi berdasarkan kesepakatan para pihak sedangkan kerugian di tanggung bersama sesuai dengan proporsi penyertaan modal masing-masing pihak. Fakta real di lapangan yaitu akad yang berlangsung antara pemilik modal dan pengelola, dimana upah Rp 1200 per kg ayam diberikan diawal akad. Artinya, upah tersebut sudah ditetapkan diawal sebelum bisnis berjalan. Dan kita belum mengetahui berapa besar keuntungan diperoleh saat panen ayam.

Fakta di atas tidak sesuai dengan yang peneliti kutip berkaitan dengan syarat pokok musyarakah menurut Usmani: Tidak diperbolehkan untuk menetapkan lumsum untuk mitra tertentu, atau tingkat keuntungan tertentu yang dikaitkan dengan modal investasinya.

Berdasarkan analisis peneliti dapat menyimpulkan bahwa praktik kerja sama bisnis ayam potong menjawab pertanyaan kedua dari rumusan masalah bahwa praktik kerja sama bisnis ini tidak sesuai dengan akad musyarakah dimana keuntungan sudah ditetapkan diawal akad dan kerugian tidak dibagi sesuai porsi modal yang disertakan. Seharusnya dalam musyarakah keuntungan dibagi berdasarkan kesepakatan para pihak sedangkan kerugian ditanggung bersama sesuai dengan proporsi penyertaan modal masing-masing pihak.

\section{Latar Belakang Praktik Kerja Sama Bisnis Ayam Potong di Kecamatan Jekan Raya}

Awal dari praktik kerja sama bisnis ayam potong ini didahului dengan mendatangi Rajawali PS dan melakukan akad. Tahap awal, persiapan kandang, pembersihan, sterilisasi kandang disertai persiapan pemanas (drum beserta kayu bakar didalamnya). Perlakuan ayam masuk, untuk mengganti tenaga ayam yang hilang selama perjalanan menggunakan air gula merah direbus atau dicairkan, setelah itu baru ayam dikeluarkan dari box, lalu dikasih minum air gula tadi selama 4-6 jam. Setelah habis diganti menggunakan vitamin. Setelah itu, besoknya dikasih vitamin sampai 3 hari berturut-turut. Hari ke-4 nya dilakukan vaksin, vaksin dilakukan dengan meneteskan cairan ke mata ayam guna menghindari penyakit yang menyerang ayam, biasanya vaksin dilakukan saat ayam berumur 4 atau 5 hari. Semakin cepat vaksin maka semakin bagus untuk kesehatan ayam. Hari ke-4 mulai pengobatan rutin. Pengobatan tiap pagi selama 2 jam maksimal lalu diganti air putih. Malamnya menggunakan vitamin terus sampai umur 30. Kalau sudah umur 30 menggunakan air putih terus tergantung situasi dan kondisinya ayam kalau ada yang mulai ngorok atau pilek dilakukan pengobatan lagi, bedanya umur 30 pengobatan dilakukan pada malam hari, jika pagi atau siang hari dilakukan pengobatan disertai cuaca panas malah tambah parah sakitnya ayam. Dilakukan pengobatan 3 hari berturut-turut jikalau berkurang sakit ayam, maka pengobatan tadi berhenti dilakukan diganti dengan menggunakan air putih. Jika pakan habis, tinggal menelpon agen Rajawali PS. Pakan diberikan tergantung umur ayam, umur 1-10 hari pakan diberikan sedikit demi sedikit dikarenakan masih dalam tahap pemanasan. Jika sudah lepas dari tahap pemanasan, maka ayam diberi makan 1 hari sekali kapasitas full 1 galon pakan. Kira-kira umur ayam 40 hari sudah siap untuk di panen, panen dilakukan oleh anak buah Rajawali PS dengan mendatangi setiap kandang. Pengelola mendapatkan upah Rp 1200,- per kilo ayam,dan upah ini dibayar setelah seminggu ayam panen.

Berdasarkan hasil analisis, peneliti menyimpulkan bahwa dari praktik di lapangan seperti di atas dipakai oleh semua subjek, yaitu RH, LL, SB, BN, MN, dan Sry. Praktik kerja sama bisnis ayam potong di lapangan memang benar demikian karena berdasarkan penuturan semua subjek memang 1 pemilik modal, sama pada praktiknya, sama pada awal kesepakatan akad dilakukan di depan dan pembagian hasil didepan pula, kerugian ditanggung sepenuhnya oleh pemilik modal, pengelola hanya main aman yaitu tetap pada harga $\mathrm{Rp} 1.200$,- per kilo. 


\section{Penerapan Bagi Hasil Praktik Kerja Sama Bisnis Ayam Potong di Kecamatan Jekan Raya dengan Berdasarkan Akad Musyarakah}

Ada beberapa hal yang peneliti jadikan acuan dalam kerja sama bisnis ayam potong berdasarkan wawancara yang peneliti lakukan dari 6 (enam) sujek penelitian ini, ada tiga rukun dari akad musyarakahyaitu (1) Pelaku akad, yaitu para mitra usaha. (2) objek akad, yaitu modal (mal), kerja (dharabah), dan keuntungan (ribh) dan (3) shighah, yaitu ijab dan qabul.

Berdasarkan uraian diatas, peneliti dapat menyimpulkan bahwa rukun pertama dari akad musyarakah yaitu pelaku akad atau para mitra usaha sudah sesuai dengan adanya pihak I dan pihak II, dimana pihak I berperan sebagai pemilik modal bertugas menyediakan mulai dari bibit ayam, pakan, obat-obatan, vaksin dan vitamin untuk memenuhi kebutuhan yang diperlukan oleh ayam, sedangkan pihak II berperan sebagai pengelola bertugas menyediakan kandang, terpal, gula merah, drum pemanas ayam, minyak tanah + kayu bakar, bayar listrik, kipas angin, bolam lampu, hitachi, dan genset serta pengelola (pebisnis) yang merawat ayam mulai dari umur 1 hari sampai siap panen ( \pm 40 hari).

Pada rukun yang kedua yaitu objek akad: modal, kerja dan keuntungan. Kedua belah pihak dalam pembahasan sebelumnya bahwa sama-sama menyediakan modal, dan pihak kedua juga bekerja (skill). Hal ini dipandang peneliti sudah sesuai, namun dalam segi pembagian keuntungan peneliti memandang belum sesuai dengan akad musyarakah karena perjanjian antara kedua belah pihak harus berakhir dengan Win Win Solution (WWS) bukan Win Lose Solution (WLS), tidak ada satu pihak yang dirugikan dan tidak ada satu pihak yang diuntungkan, seharusnya kedua belah pihak sama-sama diuntungkan karena tujuan dari bisnis itu sendiri yaitu profit oriented atau mencari keuntungan sebanyak-banyaknya.

Adapun pada rukun yang ketiga, yaitu shighah atau ijab dan qabul, peneliti memandang bahwa kedua belah pihak sudah melakukan shighah ini diawal kesepakatan, yaitu ijab dari pemilik modal dan qabul dari pengelola.

\section{PENUTUP}

Berdasarkan analisis peneliti dapat disimpulkan bahwa praktik kerja sama bisnis ayam potong studi pada Kecamatan Jekan Raya meskipun ada beberapa praktik yang sesuai dengan pendapat kalangan ulama, namun peneliti memandang praktik kerja sama bisnis ayam potong studi pada Kecamatan Jekan Raya tidak sesuai dengan akad musyarakah. Dikatakan tidak sesuai karena praktik kerja sama bisnis ayam potong yang terjadi di lapangan menggunakan sistem "hasil" yaitu Rp 1.200,- tetap tidak berubah, tidak menggunakan sistem bagi hasil dikarenakan jika tidak ada hasil maka tidak ada yang dibagi, serta keuntungan dan kerugian dari pihak pemilik modal tidak diketahui oleh pengelola karena dalam sistem musyarakah sendiri harus adanya transparansi atau keterbukaan keuntungan pihak pemilik modal dan pihak pengelola.

\section{DAFTAR PUSTAKA}

Abdurrahman Al- Gharyani, Shadiq. 2005. Buku Pintar Hukum Jual Beli Islam Kontemporer. Depok: Iqra Kurnia Gemilang.

Aldio, Muhammad, Sejarah Kota Palangka Raya, Kalimantan Tengah (1950 - 1972), http:/ / coretcoretdoang.blogspot.co.id/ 2015/ 10/ sejarah-kota-palangka-raya-kalimantan.html (Diunduh 8 Februari 2017 pukul 11:00 WIB).

Anwar, Syamsul. 2010. Hukum Perjanjian Syariah. Jakarta: PT Raja Grafindo Persada.

Arikunto, Suharsimi. 2003. Manajemen Penelitian.Jakarta: PT Rineka Cipta. 
Ascarya. 2007. Akad dan Produk Bank Syariah. Jakarta: PT RajaGrafindo Persada.

Bungin, M. Burhan. 2007. Penelitian Kualitatif : Komunikasi, Ekonomi, Kebijakan Publik dan Ilmu Sosial Lainny. Jakarta: Kencana.

Daymon, Christine dan Holloway, Immy. 2008. Metode-Metode Riset Kualitatis Dalam Public Relations dan Marketing Communication Terj. Qualitative Research Methods On Public Relation and Marketing Communications. Yogyakarta: PT Bentang Pustaka.

Departemen Agama. 2005. Al-Qur'an dan Terjemahannya. Bandung: CV Penerbit Jumanatul 'AliArt.

Djakfar, Muhammad. 2012. Etika Bisnis, Menangkap Spirit Ajaran Langit dan Pesan Moral Bumi. Jakarta: Penepar Plus.

Djuwaini, Dimyauddin. 2008. Pengantar Fikih Muamalah. Yogyakarta: Pustaka Pelajar.

\section{Fatwa DSN MUI}

Ghony, M. Djunaidi \& Almanshur, Fauzan. 2012. Metode Penelitian Kualitatif. Yogyakarta: ArRuzz Media.

https:/ / www.google.com/ search?q=skema+akad+musyarakah+dalam+kemitraan\&client=firefo $\mathrm{x}$-beta\&rls=org.mozilla:en-US:official\&channel=fflb\&tbm=isch\&tbo=u\&source=univ\&sa=X\&ved=0ahUKEwi78t677fzRAhWLMI8KHYIXCWEQsAQIIg\&biw =1366\&bih=696 (diunduh 9 februari 2017 pukul 08:00 WIB).

https:/ / www.google.com/ search?q=skema+akad+musyarakah+dalam+kemitraan\&client=firefo $\mathrm{x}$-beta\&rls=org.mozilla:en-US:official\&channel=fflb\&tbm=isch\&tbo=u\&source=univ\&sa=X\&ved=0ahUKEwi78t677fzRAhWLMI8KHYIXCWEQsAQIIg\&biw=1366\&bih=696 (Diunduh 9 Februari 2017 pukul 10:00 WIB).

https:/ / www.Kantor Urusan Agama (KUA) Kecamatan Jekan Raya, http:/ / kuajekanraya.com/ profil/ potret-singkat/ (Diunduh 8 februari 2017 pukul 14:00 WIB).

https:/ / www.Website pemerintah kota palangka raya, https:/ / palangkaraya.go.id/ pemerintahan/ visi-misi/ ( diunduh 8 februari 2017 pukul 13:00 WIB).

Immy Holloway , Christine Daymon. 2008. Metode-Metode Riset Kualitatis Dalam Public Relations Dan Marketing Communication, Terj. Qualitative Research Methods In Public Relation And Marketing Communications. Yogyakarta: PT Bentang Pustaka.

Kamus Besar Bahasa Indonesia

Mardani. 2013. Fiqh Ekonomi Syariah.Jakarta: Kencana Prenadamedia Group.

Miru, Ahmadi. 2012. Hukum Kontrak Bernuansa Islam. Jakarta: PT RajaGrafindo Persada. 
Mu'arif, Muhammad. 2014. "Studi Penerapan Syirkah dalam Bisnis Travel Mobil di Kota Palangka Raya”. Skripsi Sarjana. Palangka Raya: Sekolah Tinggi Agama Islam Negeri Palangka Raya.

Muhammad. 2007. Prinsip-prinsip Ekonomi Islam. Yogyakarta: Graha Ilmu.

Muhammad. 2008. Paradigma, Metodologi dan Aplikasi Ekonomi Syariah. Yogyakarta: Graha Ilmu.

Nasution. 2014. Metodologi Research (Penelitian Ilmiah). Bandung: Bumi Aksara.

P3EI UII Yogyakarta. 2012. Ekonomi Islam. Jakarta: Rajawali Press.

Pedoman Penulisan Skripsi Sekolah Tinggi Agama Islam Negeri Palangka Raya Tahun 2013.

Rinaldi Firmansyah, dan Rizqullah, Veithzal Rivai. 2010. Islamic Financial Management. Bogor: Ghalia Indonesia.

Siddiqi, M. Nejatullah. 1996. Kemitraan Usaha dan Bagi Hasil dalam Hukum Islam. Yogyakarta: PT Dana Bhakti Prima Yasa.

Susila Witari, Lya. 2013. “Pengaruh Penerapan Etika Bisnis terhadap Kepuasan Konsumen Ayam Potong di Pasar Tradisional Puruk Cahu". Skripsi Sarjana. Palangka Raya: Sekolah Tinggi Agama Islam Negeri (STAIN) Palangkaraya.

Tanzeh, Ahmad. 2011. Metodologi Penelitian Praktis. Yogyakarta: Teras.

Tasrifianor. 2011. "Proses Penyembelihan Ayam Potong di Kota Palangka Raya Ditinjau dari Hukum Islam". Skripsi Sarjana, Palangka Raya: Sekolah Tinggi Agama Islam Negeri Palangka Raya, 2011.

Yunia Fauzia, Ika \& Riyadi, Abdul Kadir. 2014. Prinsip Dasar Ekonomi Islam Perspektif Maqashid Al-Syariah. Jakarta: Kencana.

Yunia Fauzia, Ika. 2014. Etika Bisnis dalam Islam. Jakarta: Kencana. 


\title{
PENGARUH PERILAKU KONSUMEN DAN LABEL HALAL PRODUK MAKANAN RUMAH TANGGA TERHADAP KEPUTUSAN KONSUMSI DI PALANGKA RAYA (Keluarga Mahasiswa Ekonomi Syariah IAIN Palangka Raya)
}

\author{
Yeni Herliani, Rahmaniar, dan Fuad Muhajirn Farid \\ IAIN Palangka Raya
}

\begin{abstract}
Every individual has different manners for making choices, including choosing a need and desire. In the modern world of today has come a wide selection of products both local and international standards one of which is a food product. Namely food production in the country for food products imported from abroad, as well as processed food products such as cottage industries. Existing halal label on food products would have been very impact and influence for consumers, particularly Muslim consumers are encouraged to consume Thayyib food and halal. For this study will focus on the effect of consumer behavior and halal label food products by household to consumption decisions in Palangka Raya (Student Association of Islamic Economics at IAIN Palangka Raya) to determine the effect of consumer behavior and halal label food products by households to consumption decision analysis techniques Correlation Product Moment using SPSS 18.0.

This research is quantitative descriptive research type ex post facto, and perform data analysis with multiple regression test. Data collection methods the authors used observations and questionnaires. From the test result perfomed on the instrument 20 respondents to the uestion number 40 items declared valid and can be used to collect the data in the study sample. The population in this study were all students of Islamic Economics at IAIN Palangka Raya in force from 2012 to 2015. While the study sample were 75 respondents students of Faculty of Islamic Economics and Business, Departement of Islamic Economics at IAIN Palangka Raya, and from the number of respondents were given a qquestionnaire to be answered. Data analysis technique used is Multiple Regression.

The result of this study indicate that obtained from the F test (simultaneous) amounted tp 7.132 , then in accordance with the F test criteria then Ho is rejected. This means that there are significant effect between consumer behavior and halal label together or simultaneously on consumption decisions, the results obtained from the value of $\mathrm{R}$ Square of 0.165 which means that the consumer behavior variables (X1) and label halal food products household (X2) 16,5\% have influence on consumer decision variable (Y). while the remaining $83,5 \%$ is influenced by other factors.
\end{abstract}

Keywords: halal label, consumer behavior, consumption decision

\section{PENDAHULUAN}

Persepsi setiap individu berbeda-beda, dalam memilih, mengatur dan menafsirkan suatu pilihan produk atau barang yang akan dikonsumsinya. Tentulah bagi seorang muslim yang beriman sangat memperhatikan kejelasan atau label dari produk yang ia konsumsi. Label halal sangatlah berpengaruh dan penting. Dengan adanya akal kita dapat membedakan perkara antara yang hak dan yang bathil, yang baik dan buruk. Hendaknya produk yang kita konsumsi telah menjalani proses pemeriksaan kehalalan dan dinyatakan halal (telah memiliki sertifikat 
halal). Produk yang belum mendapat sertifikat halal atau berlabel halal tidak berarti dinyatakan haram, tapi dinyatakan tidak terjamin kehalalannya atau masih diragukan.

Banyak beredar berbagai macam bahan atau produk makanan yang masih belum ada keterangan halal atau label halal dan diragukan kejelasan proses pembuatan juga bahannya. Seperti disekitar tempat tinggal kita banyak berbagai pilihan makanan olahan kemasan yang membuat pembeli dapat memilih makanan yang diinginkan, khususnya makanan yang banyak dijual disekitar tempat perkuliahan mahasiswa ekonomi syariah. Banyak mahasiswa yang berbeda pendapat mengenai pilihan produk makanan yang ingin di konsumsi, mulai dari mempertimbangkan keinginan kebutuhan maupun melihat kemasan label produk. Setiap konsumen muslim akan memperhatikan produk makanan yang ia beli, dan dari setiap perilaku individu muslim khususnya mahasiswa mahasiswi Ekonomi Syariah IAIN Palangka Raya pasti berbeda-beda. Masih ada saja orang-orang yang menghiraukan tentang halalnya produk bahan makanan yang dibeli. Oleh karena itu dengan adanya latar belakang ini saya tertarik meneliti tentang "Pengaruh Perilaku Konsumen dan Label Halal Produk Makanan Rumah Tangga Terhadap Keputusan Konsumsi di Palangka Raya (Mahasiswa Ekonomi Syariah IAIN Palangka Raya)".

\section{Landasan Teori}

Perilaku konsumen adalah proses dan aktivitas ketika seseorang berhubungandengan pencarian, pemilihan, penggunaan, pembelian, serta pengevaluasian produk dan jasa demi memenuhi kebutuhan dan keinginan. Perilaku konsumen adalah hal yang mendasari konsumen untuk membuat keputusan pembelian. Teori perilaku konsumen (consumer behavior) mempelajari bagaimana manusia memilih diantara berbagai pilihan yang dihadapinya dengan memanfaatkan sumberdaya (resources) yang dimilikinya. ${ }^{1}$

Menurut James F Engel, Roger D Blackwell, Paul W Miniart dalam saladinterdapat tiga faktor yang mempengaruhi perilaku konsumen yaitu: 1) Pengaruh lingkungan, terdiri dari budaya, kelas sosial, keluarga dan situasi. 2) perbedaan dan pengaruh individu, terdiri dari motivasi, pengetahuan, sikap, kepribadian, gaya hidup, dan demografi. 3) proses psikologis terdiri dari pengolahan informasi, pembelajaran, perubahan sikap, dan perilaku².

Label merupakan keterangan yang melengkapi suatu kemasan barang yang berisi tentang bahan-bahan yang digunakan untuk membuat suatu barang tersebut. Labeling berkaitan erat dengan pemasaran. Label merupakan bagian dari suatu produk yang menyampaikan informasi mengenai produk dan penjual. Sebuah label bisa merupakan bagian dari kemasan, atau bisa pula merupakan etiket (tanda pengenal) yang menempel atau melekat pada produk. Label produk (product label) adalah bagian dari pengemasan sebuah produk yang mengandung informasi mengenai produk atau penjualan produk. Secara garis besar terdapat tiga macam label yaitu:

1) Brand Label, yaitu nama merek yang diberikan pada produk atau dicantumkan pada kemasan.

2) Descriptive Label, yaitu label yang memberikan informasi obyektif mengenai penggunaan, konstruksi atau pembuatan, perawatan atau perhatian dan kinerja produk, serta karakteristik-karakteristik lainnya yang berhubungan dengan produk.

3) Grade Label, label yang mengidentifikasi penilaian kualitas produk dengan suatu huruf, angka, atau kata ${ }^{3}$.

\footnotetext{
1Mustafa Edwin Nasution, dkk, Pengenalan Eksklusif Islam, Jakarta: Kencana, 2007, hal. 56.

2Ratni, Http:/ / ratni_itp.staff.ipb.ac.id, diakses pada tanggal 20 April 2016.

3Wahyu Budi Utami,http:/ / digilib.uinsuka.ac.id/ 8244/ 1/ BAB\%20I,\%20IV,\%20DAFTAR\%20PUSTAKA.pdf., diakses pada tanggal 18 maret 2016.
} 
Terdapat beberapa faktor internal yang relevan terhadap proses pengambilan keputusan konsumen:

1) Motivasi (motivation) merupakan suatu dorongan yang ada dalam diri manusia untuk mencapai tujuan tertentu.

2) Persepsi (perception) merupakan hasil pemaknaan seseorang terhadap stimulus atau kejadian yang diterimanya berdasarkan informasi dan pengalamannya terhadap rangsangan tersebut.

3) Pembentukan sikap (attitude formation) merupakan penilaian yang ada dalam diri seseorang yang mencerminkan sikap suka/ tidak suka seseorang akan suatu hal.

4) Integritas (integration) merupakan kesatuan antara sikap dan tindakan. Integrasi merupakan respon atas sikap yang diambil. Perasaan suka akan mendorong seseorang untuk membeli dan perasaan tidak suka akan membulatkan tekad seseorang untuk tidak membeli produk tersebut.

\section{HASIL DAN PEMBAHASAN}

Dalam proses pengambilan keputusan setiap orang berbeda beda, ada yang sederhana dan kompleks. Tergantung pemikiran dan kebiasaan setiap individu. Proses pengambilan keputusan membeli sebelum membeli suatu produk atau jasa, umumnya konsumen melakukan evaluasi untuk melakukan pemilihan produk atau jasa.

Sedangkan untuk menentukan signifikan dari sebuah hipotesis yang telah dirumuskan maka diperlukan kaidah keputusan yang akan dijadikan pedoman yaitu sebagai berikut.

1) Jika nilai reabilitas (taraf signifikan) 0,05 lebih kecil atau sama dengan nilai Sig atau $(0,05<$ Sig), maka Ho diterima dan Ha ditolak artinya tidak signifikan.

2) Jika nilai probabilitas 0,05 lebih besar atau sama dengan nilai Sig $(0,05>$ Sig), maka Ho ditolak dan Ha diterima artinya signifikan.4

Hipotesis:

$$
\begin{aligned}
& \text { Ho = tidak ada hubungan } \\
& \text { Ha = Ada hubungan } \\
& \text { Jika Sig. }<0,05 \text {, maka tolak Ho } \\
& \text { Jika Sig. }>0,05 \text { maka terima Ho }
\end{aligned}
$$

Menurut teori Engel (2006), dinyatakan bahwa pengambilan keputusan konsumen dipengaruhi oleh budaya, kelas sosial, pengaruh pribadi, keluarga dan situasi. Keputusan pembelian konsumen dipengaruhi faktor internal atau faktor pribadi (persepsi, keluarga, pengetahuan, sikap, usia, gaya hidup) kerap memainkan peran penting dalam pengambilan keputusan konsumen ${ }^{5}$. Menurut Engel, Blakckwell \& miniard faktor yang mempengaruhi perilaku konsumen untuk melakukan keputusan pembelian adalah salah satunya pengaruh lingkungan dan pengaruh individual. menurut Engel (2006) faktor internal (pribadi) keputusan pembelian konsumen juga dipengaruhi oleh pengetahuan produk. Engel juga menjelaskan bahwa pengetahuan produk meliputi: kesadaran akan kategori dan merek produk di dalam kategori produk, terminology produk, atribut dan ciri produk, dan kepercayaan tentang kategori produk secara umum mengenai merek yang spesifik ${ }^{6}$. Berdasarkan teori tersebut dapat disimpulkan perilaku konsumen

\footnotetext{
${ }_{4}$ Ridwan \& Sunarto, Pengantar Statistik untuk Penelitian: Pendidikan, Sosial, Komunikasi, Ekonomi, dan Bisnis, Bandung: Alfabeta, 2007, hal.278.

5 Etta Mamang Sangadji dan Sopiah, Perilaku Konsumen: Pendekatan Praktis, Yogyakarta: Andi Offset, 2013, hal.40.

6 Etta Mamang Sangadji dan Sopiah, Perilaku Konsumen: PendekatanPraktis, ...hal. 44.
} 
dan juga atribut merek produk memiliki pengaruh terhadap keputusan pembelian atau keputusan konsumsi.

Diketahui F hitung sebesar 7,132. Apabila menggunakan F tabel sebesar 2,732 maka dengan membandingkan antara F hitung dan F tabel diperoleh 7,132 >2,732. Berdasarkan kriteria uji F :

Ho diterima bila $F$ hitung $<$ F tabel

Ho ditolak bila $F$ hitung $>\mathrm{F}$ tabel

Berdasarkan kriteria uji F tersebut, maka Ho ditolak. Artinya ada pengaruh secara signifikan antara perilaku konsumen dan label halal secara bersama-sama atau serentak terhadap keputusan konsumsi. Dan dapat disimpulkan bahwa perilaku konsumen dan label halal berpengaruh terhadap keputusan konsumsi di Palangka Raya (Keluarga mahasiswa ekonomi syariah IAIN Palangka Raya).

Berdasarkan hasil analisis statistik uji t pada (tabel 4.12) didapatkan model dari keputusan konsumsi yang dipengaruhi oleh variabel perilaku konsumen dan label halal produk makanan rumah tangga, sesuai model umum sebagai berikut: keputusan konsumsi $(\mathrm{Y})=34,344+$ 0,524* perilaku konsumen $(\mathrm{X} 1)+0,415 *$ Label halal produk makanan rumah tangga $(\mathrm{X} 2)$. Dimana kedua variabel tersebut yaitu perilaku konsumen dan label halal produk makanan rumah tangga berpengaruh signifikan terhadap keputusan konsumsi. Dapat dilihat dari nilai t yang sesuai dengan hipotesisnya jika nilai t hitung $>$ dari $\mathrm{t}$ tabel atau $\mathrm{Sig}<0,05$, maka $\mathrm{H}_{0}$ ditolak yang artinya variabel-variabel tersebut berpengaruh signifikan terhadap variabel respon atau keputusan konsumsi.

Selanjutnya akan dilihat apakah model tersebut sesuai dengan kriteria Goodness of fit (kebaikan model) dapat dilihat dari tabel Anova (tabel 4.13) didapatkan nilai f sebesar 7,132, maka sesuai dengan hipotesis bahwa f hitung lebih besar dari $f$ tabel atau nilai Sig. $<0,05$ maka $\mathrm{H}_{0}$ ditolak yang artinya model tersebut dengan variabel-variabel bebas $(\mathrm{X})$ berpengaruh terhadap variabel terikat (Y) Signifikan, sehingga model tersebut sudah sesuai dengan kriteria Goodness of fit (kebaikan model). Artinya, ada pengaruh secara signifikan antara perilaku konsumen dan label halal secara bersama-sama atau serentak terhadap keputusan konsumsi. Dan dapat disimpulkan bahwa perilaku konsumen dan label halal berpengaruh terhadap keputusan konsumsi di Palangka Raya (Keluarga mahasiswa ekonomi syariah IAIN Palangka Raya). Hasil penelitian juga menunjukkan bahwa nilai R Square sesuai dengan (tabel 4.14) sebesar 0,165 yang dapat diartikan bahwa variabel perilaku konsumen dan label halal produk makanan rumah tangga mempunyai pengaruh sebesar 16,5\% terhadap variabel keputusan konsumsi, sedangkan 83,5\% sisanya variabel keputusan konsumsi dipengaruhi oleh faktor-faktor lain di luar dari variabel perilaku konsumen dan label halal.

Variabel perilaku konsumen dan label halal produk makanan rumah tangga memiliki pengaruh yang signifikan terhadap hubungan antara keputusan konsumsi, maka hipotesis kedua yang menyatakan bahwa perilaku konsumen dan label halal berpengaruh terhadap keputusan konsumsi dapat dibuktikan kebenarannya.

Bedasarkan data yang telah diuraikan pada bab-bab sebelumnya dengan menggunakan analisis regresi linear ganda, maka dapat disimpulkan sebagai berikut:

Hasil yang didapatkan dari uji $\mathrm{F}$ (serentak) sebesar 7,132, maka sesuai dengan tersebut maka Ho ditolak. Artinya, ada pengaruh secara signifikan antara perilaku konsumen dan label halal secara bersama-sama atau serentak terhadap keputusan konsumsi. Dan dapat disimpulkan bahwa perilaku konsumen dan label halal berpengaruh terhadap keputusan konsumsi di Palangka Raya (Keluarga mahasiswa ekonomi syariah IAIN Palangka Raya).

Berdasarkan kaidah keputusan dari hipotesis, nilai probabilitas 0,05 lebih besar atau sama dengan nilai probabilitas Sig. Atau $(0,000<0,05)$, maka Ho ditolak dan Ha diterima, artinya 
signifikan.Hasil penelitian juga menunjukkan bahwa nilai R Square sebesar sebesar 0,165 yang dapat diartikan bahwa variabel perilaku konsumen dan label halal produk makanan rumah tangga mempunyai pengaruh sebesar 16,5\% terhadap variabel keputusan konsumsi, sedangkan 83,5\% lainnya dipengaruhi oleh faktor-faktor di luar dari variabel perilaku konsumen dan label halal.

\section{PENUTUP}

Hasil penelitian ini menunjukkan bahwa diperoleh dari uji F (serentak) sebesar 7,132, maka sesuai dengan kriteria uji $\mathrm{F}$ tersebut maka Ho ditolak. Artinya, ada pengaruh secara signifikan antara perilaku konsumen dan label halal secara bersama-sama atau serentak terhadap keputusan konsumsi. Dan dapat disimpulkan bahwa perilaku konsumen dan label halal berpengaruh terhadap keputusan konsumsi di Palangka Raya (Keluarga Mahasiswa Ekonomi Syariah IAIN Palangka Raya).

Berdasarkan kaidah keputusan dari hipotesis, nilai probabilitas 0,05 lebih besar atau sama dengan nilai probabilitas Sig. Atau $(0,000<0,05)$, maka Ho ditolak dan Ha diterima, artinya signifikan.Hasil penelitian juga menunjukkan bahwa nilai R Square sebesar sebesar 0,165 yang dapat diartikan bahwa variabel perilaku konsumen dan label halal produk makanan rumah tangga mempunyai pengaruh sebesar 16,5\% terhadap variabel keputusan konsumsi, sedangkan 83,5\% lainnya dipengaruhi oleh faktor-faktor di luar dari variabel perilaku konsumen dan label halal. Hal ini dapat menjelaskan bahwa pengaruh perilaku konsumen dan label halal produk makanan rumah tangga terhadap keputusan konsumsi di Palangka Raya berpengaruh.

\section{DAFTAR PUSTAKA}

Ahsin, W Alhafidz. 2010. Fikih Kesehatan. Jakarta: Amzah.

Al Arif, M Nur Rianto. 2010. Teori Mikro Ekonomi. Jakarta: Kencana.

Arikunto, Suharsimi. 1998. Penelitian Suatu Pendekatan Praktek. Jakarta: Rineka Cipta

Bakri, Asafri Jaya. 1996. Konsep Maashid Syari’ah. Jakarta: PT Raja Grafindo Persada.

Bungin, Burhan.2006. Metodologi Penelitian Kuantitatif: Komunikasi, Ekonomi, dan Kebijakan Publik Serta Ilmu-ilmu Lainnya. Jakarta: Kencana.

Consuelo G. Sevilla, dkk. 2006. Pengantar Metode Penelitian. Jakarta: UI-Press.

Darmawan, Deni. 2013. Metode Penelitian Kuantitatif. Bandung: PT Remaja Rosdakarya.

Fauzia, Ika Yunia, dan Abdul Kadir Riyadi. 2014. Prinsip Ekonomi Islam (Perspektif Maqashid alSyari'ah) Jakarta: Kencana.

Husein Umar. 2011. Metode Penelitian Untuk Skripsi dan Tesis Bisnis. Jakarta: Rajawali Pers.

Indrawan WS. 2013. Kamus Lengkap Bahasa Indonesia.Jombang: Lintas Media Jombang.

Jusmaliani. 2008. Bisnis Berbasis Syariah. Jakarta: Bumi Aksara.

Karim, Adiwarman A. 2007. Ekonomi Mikro Islam. Jakarta: PT Raja Grafindo Persada. 
Mardalis. 2004. Metode Penelitian Suatu Pendekatan Proposal, Jakarta: Bumi Aksara.

Muflih, Muhammad. 2006. Perilaku Konsumen Dalam Perspektif Ilmu Ekonomi Islam. Jakarta: PT Raja Grafindo. 2006.

Mustafa Edwin Nasution, dkk. 2007. Pengenalan Eksklusif Islam. Jakarta: Kencana.

Philip Kotler, Kevin Lane Keller. 2008. Manajemen Pemasaran. Indonesia: Macanan Jaya Cemerlang.

Pusat Pengkajian dan Pengembangan Ekonomi Islam (P3EI) Universitas Islam Indonesia Yogyakarta. 2008. Ekonomi Islam. Jakarta: PT Raja Grafindo Persada.

Qardhawi, Yusuf. 2005. Halal dan Haram Dalam Islam. Rembang: Karya Utama Surabaya.

Riduwan. 2010. Metode dan Teknik Menyusun Tesis. Bandung: Alfabeta.

Shaleh, Abdul Rahman, dan Muhbib Abdul Wahab. 2004. Psikologi dalam Suatu Pengantar Perspektif Islam. Jakarta: Kencana.

Sudjino, Anas. 2010. Pengantar Statistis Pendidikan. Jakarta: Rajawali Press.

Sugiyono. 2009. Metode Penelitian Bisnis Pendekatan Kuantitatif , Kualitatif, dan R\&D. Bandung: Alfabeta.

Syekh Muhammad Yusuf Qardhawi. 2003. Halal dan Haram dalam Islam. Surabaya: PT Bina Ilmu Offset.

Tim Penulis. 2003. Buku Pedoman Strategi Kampanye Sosial Produk Halal.Jakarta: Depag RI.

Tim penulis. 2013. Pedoman Verifikasi Produk Halal. Jakarta: Proyek Pembinaan Pangan Halal.

Wahbah Az-Zuhaili. 2011. Fiqih Islam Wa Adillatuhu. Jakarta: Darul Fikr.

Youdsa Amirman. 1993. Penelitian dan Statistik Pendekatan. Jakarta: Bumi Aksara. 